\title{
In vivo PET imaging of beta-amyloid deposition in mouse models of Alzheimer's disease with a high specific activity PET imaging agent $\left[{ }^{18} \mathrm{~F}\right]$ flutemetamol
}

Anniina Snellman ${ }^{1 *}$, Johanna Rokka², Francisco R López-Picón ${ }^{1}$, Olli Eskola², Mario Salmona ${ }^{3}$, Gianluigi Forloni ${ }^{3}$, Mika Scheinin ${ }^{4,5}$, Olof Solin², Juha O Rinne ${ }^{6}$ and Merja Haaparanta-Solin ${ }^{1}$

\begin{abstract}
Background: The purpose of the study was to evaluate the applicability of ${ }^{18} \mathrm{~F}$-labelled amyloid imaging positron emission tomography (PET) agent $\left[{ }^{18}\right.$ F $]$ flutemetamol to detect changes in brain beta-amyloid (A $\beta$ ) deposition in vivo in APP23, Tg2576 and APPswe-PS1dE9 mouse models of Alzheimer's disease. We expected that the high specific activity of $\left[{ }^{18} \mathrm{~F}\right] \mathrm{flutemetamol}$ would make it an attractive small animal $A \beta$ imaging agent.

Methods: $\left[{ }^{18} \mathrm{~F}\right]$ flutemetamol uptake in the mouse brain was evaluated in vivo at 9 to 22 months of age with an Inveon Multimodality PET/CT camera (Siemens Medical Solutions USA, Knoxville, TN, USA). Retention in the frontal cortex (FC) was evaluated by Logan distribution volume ratios (DVR) and FC/cerebellum (CB) ratios during the late washout phase (50 to $60 \mathrm{~min}$ ). $\left.{ }^{18} \mathrm{~F}\right]$ flutemetamol binding to $A \beta$ was also evaluated in brain slices by in vitro and ex vivo autoradiography. The amount of $A \beta$ in the brain slices was determined with Thioflavin $S$ and anti-A $\beta_{1-40}$ immunohistochemistry.

Results: In APP23 mice, $\left[{ }^{18} \mathrm{~F}\right]$ flutemetamol retention in the $\mathrm{FC}$ increased from 9 to 18 months. In younger mice, DVR and $F C / C B_{50-60}$ were $0.88(0.81)$ and $0.88(0.89)$ at 9 months $(N=2)$, and $0.98(0.93)$ at 12 months $(N=1)$, respectively. In older mice, DVR and $\mathrm{FC} / \mathrm{CB}_{50-60}$ were $1.16(1.15)$ at 15 months $(N=1), 1.13(1.16)$ and $1.35(1.35)$ at 18 months $(N=2)$, and 1.05 (1.31) at 21 months $(N=1)$. In Tg2576 mice, DVR and FC/CB $50-60$ showed modest increasing trends but also high variability. In APPswe-PS1dE9 mice, DVR and FC/CB ${ }_{50-60}$ did not increase with age. Thioflavin $S$ and anti-A $\beta_{1-40}$ positive $A \beta$ deposits were present in all transgenic mice at 19 to 22 months, and they co-localized with $\left[{ }^{18}\right.$ F]flutemetamol binding in the brain slices examined with in vitro and ex vivo autoradiography.

Conclusions: Increased $\left[{ }^{18}\right.$ F]flutemetamol retention in the brain was detected in old APP23 mice in vivo. However, the high specific activity of $\left[{ }^{18} \mathrm{~F}\right] f$ lutemetamol did not provide a notable advantage in Tg2576 and APPswe-PS1dE9 mice compared to the previously evaluated structural analogue $\left[{ }^{11} \mathrm{C}\right] \mathrm{PIB}$. For its practical benefits, $\left[{ }^{18} \mathrm{~F}\right]$ flutemetamol imaging with a suitable mouse model like APP23 is an attractive alternative.
\end{abstract}

Keywords: Alzheimer's disease; $\left[{ }^{18} \mathrm{~F}\right]$ flutemetamol; Preclinical evaluation; Beta-amyloid; Transgenic mouse model; High specific activity; APP23; Tg2576; APPswe-PS1dE9; Amyloid imaging

\footnotetext{
* Correspondence: aepakk@utu.fi

${ }^{1}$ Medicity/PET Preclinical Laboratory, Turku PET Centre, University of Turku,

Tykistökatu 6 A, Turku 20520, Finland

Full list of author information is available at the end of the article
} 


\section{Background}

Alzheimer's disease (AD) is the most common cause of dementia. The main pathological findings in a typical AD brain are neurofibrillary tangles and extracellular neuritic plaques, mainly composed of a fibrillar form of beta-amyloid $(\mathrm{A} \beta)$ peptide [1]. Methods based on molecular imaging have recently made it possible to assess brain $\mathrm{A} \beta$ deposition in patients with $\mathrm{AD}$. Positron emission tomography (PET) with the $A \beta$ imaging agent $\left[{ }^{11} \mathrm{C}\right]$ Pittsburgh compound $\mathrm{B}\left(\left[{ }^{11} \mathrm{C}\right] \mathrm{PIB}\right)$ first established this as a valuable biomarker approach for evaluating changes in $A \beta$ deposition [2,3]. Several small animal PET imaging studies have also been performed with $\left[{ }^{11} \mathrm{C}\right] \mathrm{PIB}$, but the results have not been consistent, probably reflecting differences in specific activity of the tracer and in the employed animal models [4-8]. Due to the short half-life $\left(T_{1 / 2}=20.4 \mathrm{~min}\right)$ of ${ }^{11} \mathrm{C},{ }^{18} \mathrm{~F}$-labelled ligands for $A \beta$ imaging have been developed to extend the use of amyloid PET to the centres without on-site radionuclide production and tracer synthesis capacity. Due to their practical benefits, the use of ${ }^{\mathbf{1 8}}$ F-labelled tracers has also raised interest in small animal imaging [9-11].

$\left[{ }^{18} \mathrm{~F}\right]$ flutemetamol (2-(3- $\left[{ }^{18} \mathrm{~F}\right]$ fluoro-4-(methylamino)phenyl)1,3-benzothiazol-6-ol, $\quad\left[{ }^{18} \mathrm{~F}\right] 3^{\prime} \mathrm{F}-\mathrm{PiB}, \quad\left[{ }^{18} \mathrm{~F}\right]$ GE067) is a ${ }^{18} \mathrm{~F}$-labelled analogue of $\left[{ }^{11} \mathrm{C}\right] \mathrm{PIB}$ developed and marketed by GE Healthcare (Buckinghamshire, UK). $\left[{ }^{18} \mathrm{~F}\right]$ flutemetamol PET has been shown to successfully differentiate between patients with $\mathrm{AD}$ and healthy control subjects and to perform similarly to $\left[{ }^{11} \mathrm{C}\right] \mathrm{PIB}$ in this respect $[12,13]$. $\left[{ }^{18} \mathrm{~F}\right]$ flutemetamol has shown high test-retest reliability and high specificity $(96 \%,[12])$ and sensitivity $(93 \%,[12])$ in the detection of $\mathrm{AD}$, and regional imaging results obtained with it were consistent with $\mathrm{AD}$ plaque pathology in cortical biopsy samples [14-16]. Based on these findings, $\left[{ }^{18} \mathrm{~F}\right]$ flutemetamol received FDA approval as a diagnostic agent for the assessments of $A \beta$ deposition in the brains of adults evaluated for AD (FDA application number (NDA) 203137, GE Healthcare).

The present demonstration of principle study evaluated the applicability of $\left[{ }^{\mathbf{1 8}} \mathrm{F}\right]$ flutemetamol to detect and quantitate the changes in brain A $\beta$ deposition in APP23, Tg2576 and APPswe-PS1dE9 transgenic (TG) mouse models of AD. We expected that the very high specific activity of $\left[{ }^{18} \mathrm{~F}\right]$ flutemetamol $(>1 \mathrm{TBq} / \mu \mathrm{mol})$ and thus lower injected mass to transgenic animals would be beneficial in small animal $\mathrm{A} \beta$ imaging. We also expected physical characteristics and practical benefits of the ${ }^{18} \mathrm{~F}$-radionuclide to make $\left[{ }^{18} \mathrm{~F}\right]$ flutemetamol an attractive preclinical $A \beta$ imaging agent for preclinical studies.

\section{Methods}

Synthesis of $\left[{ }^{18} \mathrm{~F}\right]$ flutemetamol

$\left[{ }^{18} \mathrm{~F}\right]$ flutemetamol was produced with a FASTLab ${ }^{\circ}$ Synthesizer (GE Healthcare), following analogous procedures to those described in the patent, WO 2007/020400 A1 'Fluorination process of anilide derivatives and benzothiazole fluorinate derivatives as in vivo imaging agents'. The specific radioactivity of $\left[{ }^{\mathbf{1 8}} \mathrm{F}\right]$ flutemetamol was $>1 \mathrm{TBq} / \mu \mathrm{mol}$ at synthesis completion $(N=34)$. Radiochemical purity exceeded $92 \%$.

\section{Animal models}

All animal experiments were approved by the Animal Experiment Board of the Province of Southern Finland (permissions ESAVI-2010-04454/Ym-23 and ESAVI/ $3899 / 04.10 .07 / 2013$ ) and the animal care complied with the guidelines of the International Council of Laboratory Animal Science (ICLAS). For in vivo imaging, we used mice from three different TG mouse lines and their strain-matched wild-type (WT) control animals. APP23 mice (APPswe [17]; Novartis Pharma (Basel, Switzerland); $N=4$ TG females, 2 TG males and 4 WT females) overexpress the human 751 isoform of amyloid precursor protein (APP), which contains the Swedish K670N/M671L double mutation (APPswe). These mice develop $A \beta$ plaques with dense cores, similar to human plaques, vascular $A \beta$, and neuron loss in the hippocampal CA1 pyramidal cell layer [18]. $\mathrm{Tg} 2576$ mice (APPswe, B6; SJL-Tg(APPSWE) 2576Kha [19]; Taconic Europe. Ejby, Denmark; $N=4$ TG females, 3 WT females) express the human 695 isoform of APPswe, which leads to expression of mutant $A \beta, A \beta$ plaques and memory deficits. APPswe-PS1dE9 mice (B6C3-Tg(APPswe, PSEN1DE9)85Dbo/J [20]; Jackson Laboratories, Bar Harbor, ME, USA; $N=4$ TG females, 3 TG males, 3 WT females) express a chimeric mouse/human 695 isoform of APPswe and mutant human Presenilin-1 (PS1dE9). The APPswe-PS1dE9 model mimics early-onset familial $A D$, with elevated $A \beta_{1-40}$ and $A \beta_{1-42}$ levels, abundant plaque pathology and memory deficits [21]. The APPswe-PS1dE9 male mice used in ex vivo studies were a kind gift from Professor $\mathrm{H}$. Tanila from the University of Eastern Finland. The animals were group-housed at the Central Animal Laboratory of the University of Turku at controlled temperature $\left(21 \pm 3^{\circ} \mathrm{C}\right)$ and humidity $(55 \pm$ $15 \%$ ) and with a light period from 6:00 a.m. to 6:00 p.m. TG and WT mice were fed with a soy-free diet (RM3 (E) soya, 801710, Special Diets Service, Essex, UK). The animals had free access to food and tap water (summary of animals, Table 1).

\section{PET imaging}

In vivo $\left[{ }^{18} \mathrm{~F}\right]$ flutemetamol $\mathrm{PET}$ imaging was performed at $9,12,15,18$ to 19 , and 21 to 22 months of age (in all 48 PET scans). At each time point, 1 to 4 TG and WT mice of each model were imaged (Table 1). Animals were anaesthetized with isoflurane, and computed tomography (CT) scans were acquired for attenuation correction and anatomical reference. Next, simultaneous 
Table 1 Summary of the animals used for PET experiments

\begin{tabular}{lllllll}
\hline & \multicolumn{2}{l}{ APP23 } & \multicolumn{2}{l}{ Tg2576 } & \multicolumn{2}{l}{ APPswe-PS1dE9 } \\
\hline & TG & WT & TG & WT & TG & WT \\
All mice $(N)$ & 6 & 4 & 4 & 3 & 7 & 3 \\
In vivo PET $(N)$ & & & & & & \\
9 mo & 2 & - & 2 & - & 2 & - \\
12 mo & 1 & - & 4 & 2 & 3 & 2 \\
15 mo & 1 & - & 4 & 3 & 2 & 3 \\
18 to 19 mo & 2 & - & 2 & 2 & 2 & 3 \\
21 to 22 mo & 1 & 1 & 2 & 1 & - & - \\
27 mo & - & 1 & - & - & - & - \\
Ex vivo ARG (N) & & & & & & - \\
18 to 19 mo & - & - & - & - & 4 & 1 \\
21 to 22 mo & - & - & 1 & 1 & - & - \\
24 to 27 mo & 2 & 2 & - & - & - & - \\
\hline
\end{tabular}

Amount of transgenic (TG) and wild-type (WT) animals used in this study. not available; ARG, autoradiography; mo, age in months.

with an i.v. injection of $4.3 \pm 0.9 \mathrm{MBq}(<5.5 \mathrm{ng}, \mathrm{N}=48)$ of $\left[{ }^{18} \mathrm{~F}\right]$ flutemetamol, a 60-min dynamic emission scan was started with an Inveon PET/CT device (Siemens Medical Solutions USA, Knoxville, TN, USA). Dynamic imaging data were divided into 51 imaging frames $(30 \times$ $10 \mathrm{~s}, 15 \times 60 \mathrm{~s}, 4 \times 300 \mathrm{~s}, 2 \times 600 \mathrm{~s}$ ); 3D imaging data were rebinned into $2 \mathrm{D}$ sinograms with a Fourier rebinning algorithm and then reconstructed with $2 \mathrm{D}$ filtered backprojection, with a final voxel size of $0.78 \times 0.78 \times 0.80 \mathrm{~mm}$. Data were decay-corrected to the time of injection.

\section{Analysis of PET data}

PET data were analysed with Inveon Research Workplace analysis software (Siemens Medical Solutions). PET and CT images were co-registered, and volumes of interest (VOI) were drawn under guidance of the CT image and a mouse brain atlas to cover the whole brain, the frontal cortex (FC) and the cerebellum (CB). Logan distribution volume ratios (DVR) were calculated from the dynamic PET data with the graphical method described by Logan et al. [22], with $C B$ as the reference tissue and fit time from 5 to $60 \mathrm{~min}$. FC/CB ratio curves were calculated for the entire 60-min scan. In addition, static FC/CB retention ratios were calculated only for the late phase (50 to $60 \mathrm{~min}$ ) of the scan.

\section{In vitro binding experiment}

In vitro binding experiments were performed as previously described [9] with 20- $\mu \mathrm{m}$ brain cryosections from transgenic APP23 $(N=2)$, Tg2576 $(N=2)$ and APPswePS1dE9 $(N=2)$ mice and wild-type control mice $(N=5)$ that were sacrificed after in vivo studies were finalized (Table 2). Briefly, the brain sections were incubated in
Table 2 Summary of the brain tissue used for in vitro experiments

\begin{tabular}{|c|c|c|c|c|c|c|}
\hline & \multicolumn{2}{|l|}{ APP23 } & \multicolumn{2}{|c|}{$\operatorname{Tg} 2576$} & \multicolumn{2}{|c|}{ APPswe-PS1dE9 } \\
\hline & $\begin{array}{l}\text { TG } \\
\text { (mo) }\end{array}$ & $\begin{array}{l}\text { WT } \\
\text { (mo) }\end{array}$ & $\begin{array}{l}\text { TG } \\
(\mathrm{mo})\end{array}$ & $\begin{array}{l}\text { WT } \\
\text { (mo) }\end{array}$ & $\begin{array}{l}\text { TG } \\
\text { (mo) }\end{array}$ & $\begin{array}{l}\text { WT } \\
\text { (mo) }\end{array}$ \\
\hline $\begin{array}{l}\text { In vitro } \\
\text { ARG }\end{array}$ & 18,21 & 27 & 22 & 22 & 19 & 19 \\
\hline$A \beta_{1-40}$ & 21,27 & 24,27 & 22 & 22 & 17,19 & 19 \\
\hline $\begin{array}{l}\text { Thioflavin } \\
\text { S }\end{array}$ & 21,27 & 24,27 & 22 & 22 & 17,19 & 19 \\
\hline
\end{tabular}

$0.5 \mathrm{MBq} / \mathrm{ml}\left[{ }^{\mathbf{1 8}} \mathrm{F}\right]$ flutemetamol in $2 \%$ human serum albumin for $30 \mathrm{~min}$. The specificity of $\left[{ }^{\mathbf{1 8}} \mathrm{F}\right]$ flutemetamol binding was evaluated by adding $10 \mu \mathrm{M}$ non-radioactive PIB (ABX, Radeberg, Germany) to the incubation solution, as previously described [9]. $\left[{ }^{\mathbf{1 8}} \mathrm{F}\right]$ flutemetamol binding was detected using digital autoradiography ( $25 \mu \mathrm{m}$ resolution).

\section{Ex vivo autoradiography}

Mice were anaesthetized with isoflurane and intravenously injected with $9.1 \pm 1.7 \mathrm{MBq}(<7.5 \mathrm{ng}, N=11)$ of $\left[{ }^{18} \mathrm{~F}\right]$ flutemetamol. After the tracer had distributed for $30 \mathrm{~min}$, the mice were sacrificed by cardiac puncture. The brain was immediately dissected, rapidly frozen in chilled isopentane, and cut to $20-\mu \mathrm{m}$ cryosections at the levels of the FC and CB. Sections were subsequently exposed to an imaging plate for approximately $4 \mathrm{~h}$. Plates were read with a Fuji BAS-5000 analyser (resolution $25 \mu \mathrm{m})$. Regions of interest (ROI) were drawn onto the $\mathrm{FC}$ and $\mathrm{CB}$ with the Aida Image Analyzer analysis program (Aida 4.22, Raytest Isotopenmessgeräte $\mathrm{GmbH}$, Straubenhardt, Germany). ROIs were drawn onto at least ten sections per animal, and mean intensity ratios were calculated between the FC and the CB. In addition, intensity profiles were drawn across the cortex that contained $A \beta$ deposits, and $A \beta$ plaque-to-background ratios were calculated for TG mice.

\section{Ex vivo biodistribution}

We further investigated $\left[{ }^{\mathbf{1 8}} \mathrm{F}\right]$ flutemetamol binding to different brain regions and structures inside the head in WT male $\mathrm{C} 57 \mathrm{Bl} / 6 \mathrm{~N}$ mice $(N=4)$ using ex vivo tissue counting to better understand the observed binding in vivo. Mice anaesthetized with isoflurane were injected with $5.1 \pm 0.9 \mathrm{MBq}$ of $\left[{ }^{18} \mathrm{~F}\right]$ flutemetamol, and the tracer was allowed to distribute for $60 \mathrm{~min}$. Mice were sacrificed by cardiac puncture, and the brain was rapidly removed. We dissected the forebrain, midbrain, hindbrain, olfactory bulb, medulla, eyes, Harderian glands and salivary glands, and we collected samples of FC, CB, medulla and cranial bone. ${ }^{18}$ F-radioactivity was measured with a gamma counter (2480 WIZARD ${ }^{2}$, PerkinElmer, 
Turku, Finland). Measurements were decay-corrected, the background was subtracted and results were expressed as the percentage of injected dose per gram of tissue $(\% \mathrm{ID} / \mathrm{g})$.

\section{Histological and immunohistochemical characterization of brain $A \beta$ deposits}

In the same cryosections subjected to ex vivo and in vitro autoradiography, fibrillar $\mathrm{A} \beta$ deposits were measured with the histochemical dye, Thioflavin S (ThS; Sigma-Aldrich, St. Louis, MO, USA), as previously reported [9]. A $\beta$ pathology was also evaluated in adjacent tissue sections by immunohistochemical staining with an anti-A $\beta_{1-40}$ (1:400; Millipore Corp., Billerica, MA, USA) antibody, as previously reported [4]. The mice used for brain histology are presented in Table 2. All sections were post-fixed in $4 \%$ paraformaldehyde for $30 \mathrm{~min}$ before staining. Fluorescent images were examined with a SteREO Lumar V.12 microscope (Carl Zeiss Microscopy $\mathrm{GmbH}$, Jena, Germany), and the images were captured with a Zeiss Axiocam HRm S/N 1475 camera. Images of 3, 3'-diaminobenzidine stained sections were digitized with the Pannoramic 250 Flash II digital slide scanner (3DHistech, Budapest, Hungary), and the images were captured with the Pannoramic Viewer software.

\section{Data analysis and statistics}

All mean values are expressed as mean \pm SD. Results for less than three animals are given as individual values. Linear regression analysis was performed using GraphPad Prism software (version 5.01, La Jolla, CA, USA). $P$ values $<0.05$ were considered statistically significant.

\section{Results}

\section{PET imaging}

Increased $\left[{ }^{18} \mathrm{~F}\right]$ flutemetamol retention compared to young TG animals and WT control animals was observed in the FC of aged APP23 mice in visual assessment of the PET images (Figure 1a), but not in aged Tg2576 or APPswePS1dE9 mice (Figure 1b,c). Time-radioactivity curves in Figure 2 illustrate the time-course of $\left[{ }^{18} \mathrm{~F}\right]$ flutemetamol uptake and washout in the $\mathrm{FC}$ and $\mathrm{CB}$ of representative TG animals at the final PET evaluation (at 19 to 22 months of age). The $\mathrm{FC} / \mathrm{CB}$ ratios clearly increased over time in old APP23 mice. On the contrary, in $\operatorname{Tg} 2576$ and APPswe-PS1dE9 mice, the ratio was less than 1 in the later time frames.

Logan DVRs calculated for the FCs of all TG and WT animals are presented in Figure 3a. Each individual mouse has its own symbol. The DVRs were increased in the aged APP23 TG mice compared to young TG and WT control animals. In younger TG mice, DVRs were 0.88 and 0.88 (9 months, $N=2)$ and 0.98 (12 months, $N=1)$. In older TG mice, DVRs were 1.16 (15 months, $N=1$ ), 1.13 and 1.35 (18 months, $N=2$ ), and 1.05 (21 months, $N=1$ ). DVRs for WT animals were 0.83 (21 months, $N=1$ ) and 0.98 (27 months, $N=1$ ). The DVRs of the $\operatorname{Tg} 2576$ mice showed an increasing trend, reaching 1.24 and $1.11(N=2)$ at 22 months (WT 0.92, $N=1$ ). In contrast, the APPswe-PS1dE9 mice tended to have lower DVRs $(0.82$ and $0.89, N=2)$ than WT mice $(1.08 \pm 0.12, N=3)$ at 19 months.

$\mathrm{FC} / \mathrm{CB}_{50-60}$ ratios calculated for the FCs of all TG and WT animals are presented in Figure 3b. Each individual mouse has its own symbol. The $\mathrm{FC} / \mathrm{CB}_{50-60}$ ratios increased with age in APP23 mice. The $\mathrm{FC} / \mathrm{CB}_{50-60}$ values

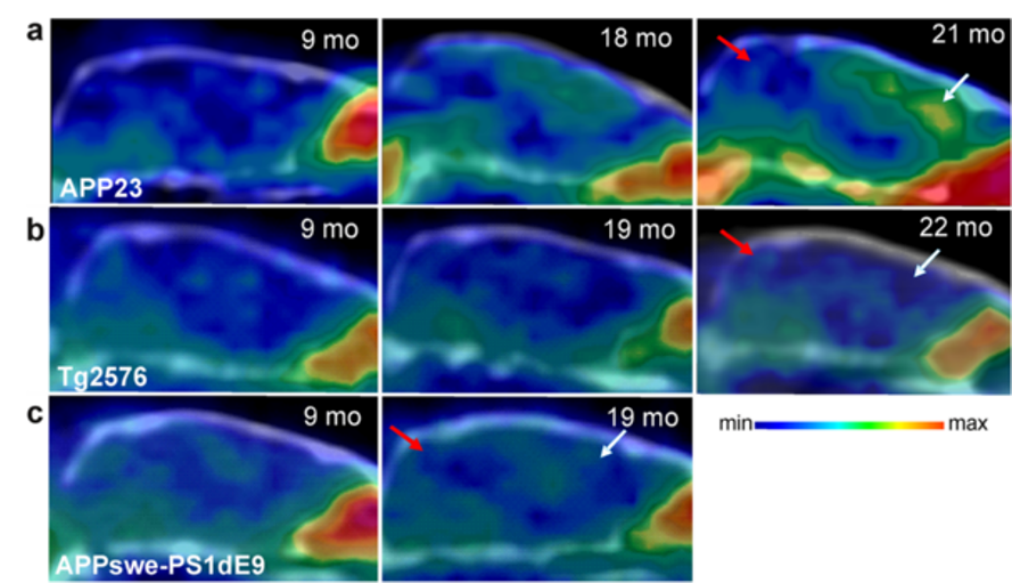

Figure 1 In vivo $\left[{ }^{18} \mathrm{~F}\right]$ flutemetamol retention in the brain of mouse models of AD. Sagittal PET/CT images summed over 40 to 60 min after $\left[{ }^{18}\right.$ F $]$ flutemetamol injection are shown for (a) APP23, (b) Tg2576 and (c) APPswe-PS1dE9 mice. Increased $\left[{ }^{18}\right.$ F $]$ flutemetamol retention (yellow) was detected in the cerebral cortex of aged APP23 mice (18 and 21 months), but signals in aged Tg2576 (19 and 22 months) and APPswe-PS1dE9 (19 months) mice were similar to those of the young ( 9 months) transgenic mice. White arrows, frontal cortex; red arrows, cerebellum; mo, age of animal in months. 


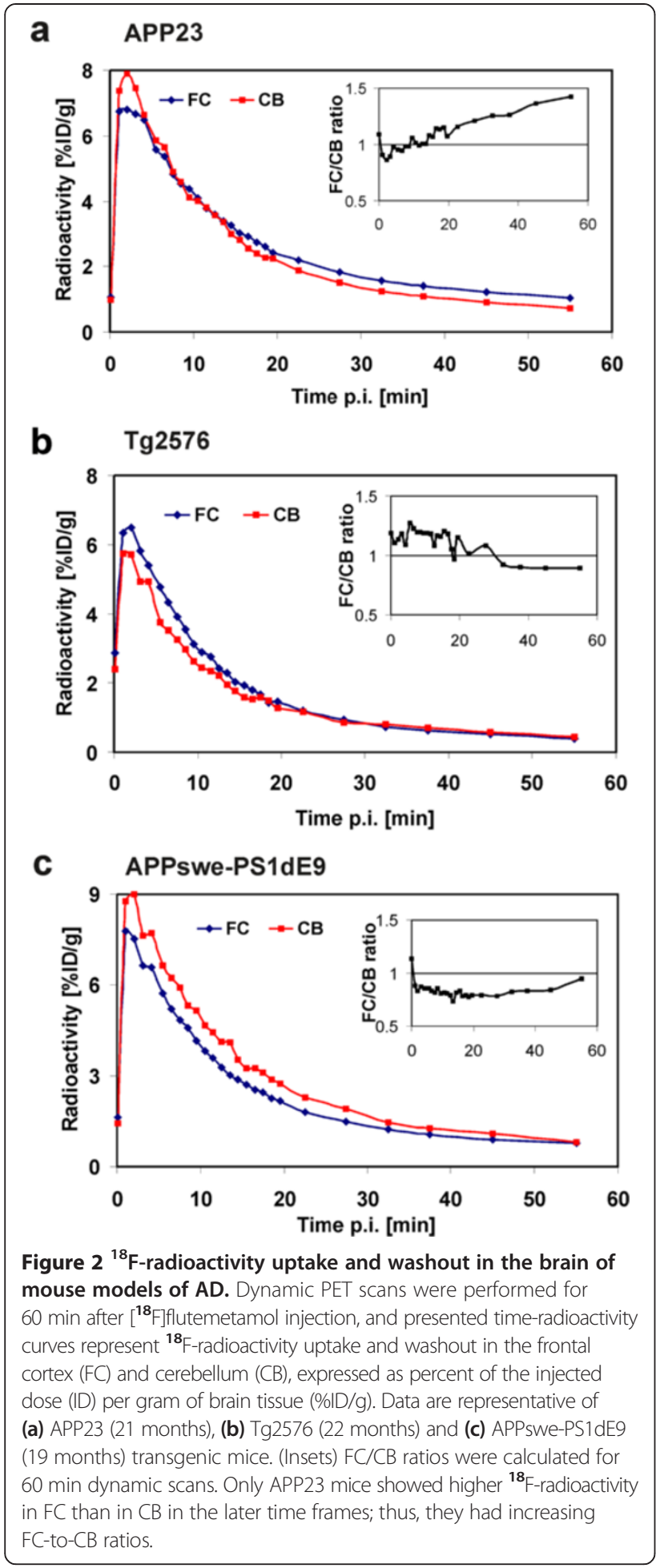

were 0.81 and 0.89 (9 months, $N=2$ ) and 0.93 (12 months, $N=1$ ) in younger TG mice, increasing to 1.15 (15 months, $N=1), \quad 1.16$ and 1.35 (18 months, $N=2$ ) and 1.31 (21 months, $N=1$ ) in older TG mice. In strain-matched WT mice, $\mathrm{FC} / \mathrm{CB}_{50-60}$ values were 0.86 (21 months, $N=1$ ) and 0.99 (27 months, $N=1$ ). In $\mathrm{Tg} 2576$ mice, $\mathrm{FC} / \mathrm{CB}_{50-60}$ values were $0.80 \pm 0.07(N=4)$ at 12 months (WT 0.81 and $0.79, N=2)$ and 0.89 and $0.99(N=2)$ at 22 months (WT $0.88, N=1$ ). In APPswe-PS1dE9 mice, $\mathrm{FC} / \mathrm{CB}_{50-60}$ remained almost stable from $0.87 \pm 0.08(N=3)$ at 12 months (WT 0.85 and $0.90, N=2$ ) to 0.95 and 0.90 $(N=2)$ at 19 months (WT $0.80 \pm 0.06, \mathrm{~N}=3$ ). The $\mathrm{FC} /$ $\mathrm{CB}_{50-60}$ ratios agreed well with the Logan DVR values in APP23 mice $\left(r^{2}=0.76, p=0.0049 ; N=9\right)$, but similar agreement was not seen in $\operatorname{Tg} 2576\left(r^{2}=0.13, \mathrm{p}=0.1046\right.$; $\mathrm{N}=22)$ or APPswe-PS1dE9 mice $\left(\mathrm{r}^{2}=0.03, \mathrm{p}=0.5256\right.$; $\mathrm{N}=17$ ) (Figure 3c).

Some transgenic mice were imaged repeatedly at several time points; this is indicated by the different symbols of individual animals in Figure 3a,b. In APP23 mice, $\mathrm{FC} / \mathrm{CB}_{50-60}$ clearly increased from 9 to 15 months and from 18 to 21 months. Also, DVR values showed clear increase from 9 to 18 months. However, one TG mouse showed lower DVR value at 21 months compared to 18 months. Some Tg2576 mice showed modest increases in $\mathrm{FC} / \mathrm{CB}_{50-60}$. Among APPswe-PS1dE9 mice, no increases were observed in individual mice subjected to repeated PET scans.

\section{In vitro binding experiment}

In all brain sections from transgenic APP23, Tg2576 and APPswe-PS1dE9 mice incubated with $\left[{ }^{18} \mathrm{~F}\right]$ flutemetamol in vitro, the bound radioactivity co-localized well with fibrillar $\mathrm{A} \beta$ plaques stained with ThS and anti- $\mathrm{A} \beta_{1-40}$ antibody (Figure 4). The punctate $\left[{ }^{18} \mathrm{~F}\right]$ flutemetamol binding was totally blocked in Tg2576 and APPswe-PS1dE9 sections co-incubated with $10 \mu \mathrm{M}$ cold PIB, but only partially blocked in APP23 sections, likely because of their very high plaque load (Figure 4).

\section{Ex vivo autoradiography}

Digital autoradiograms of the FC and $\mathrm{CB}$ were acquired from the brain sections of the three evaluated mouse models and wild-type control mice (Figure 5a). Intensity profiles (derived from the boxed regions in the FC images of Figure 5a) showed that $A \beta$ plaques emitted higher signals than the surrounding cortex; the maximum $A \beta$ plaque-to-background ratios were 3.2 and 2.6 for two APP23 mice, and 4.8 for a Tg2576 mouse. In four APPswePS1dE9 mice, $\left[{ }^{18} \mathrm{~F}\right]$ flutemetamol binding to $A \beta$ deposits in the FC was not visually equally obvious as in the APP23 and Tg2576 TG mice. The FC intensity profiles resembled those of WT control mice, and plaque-to-background ratios did not allow sharp plaque identification and were close to unity. The FC/CB ratios were clearly elevated for APP23 mice compared to WT mice (Figure $5 \mathrm{~b}$ ). The single investigated $\mathrm{Tg} 2576$ mouse also showed a higher FC/CB ratio than its WT control, but all APPswe-PS1dE9 TG mice showed lower FC/CB ratios than their WT control. High non-specific $\left[{ }^{18} \mathrm{~F}\right]$ flutemetamol binding was observed 


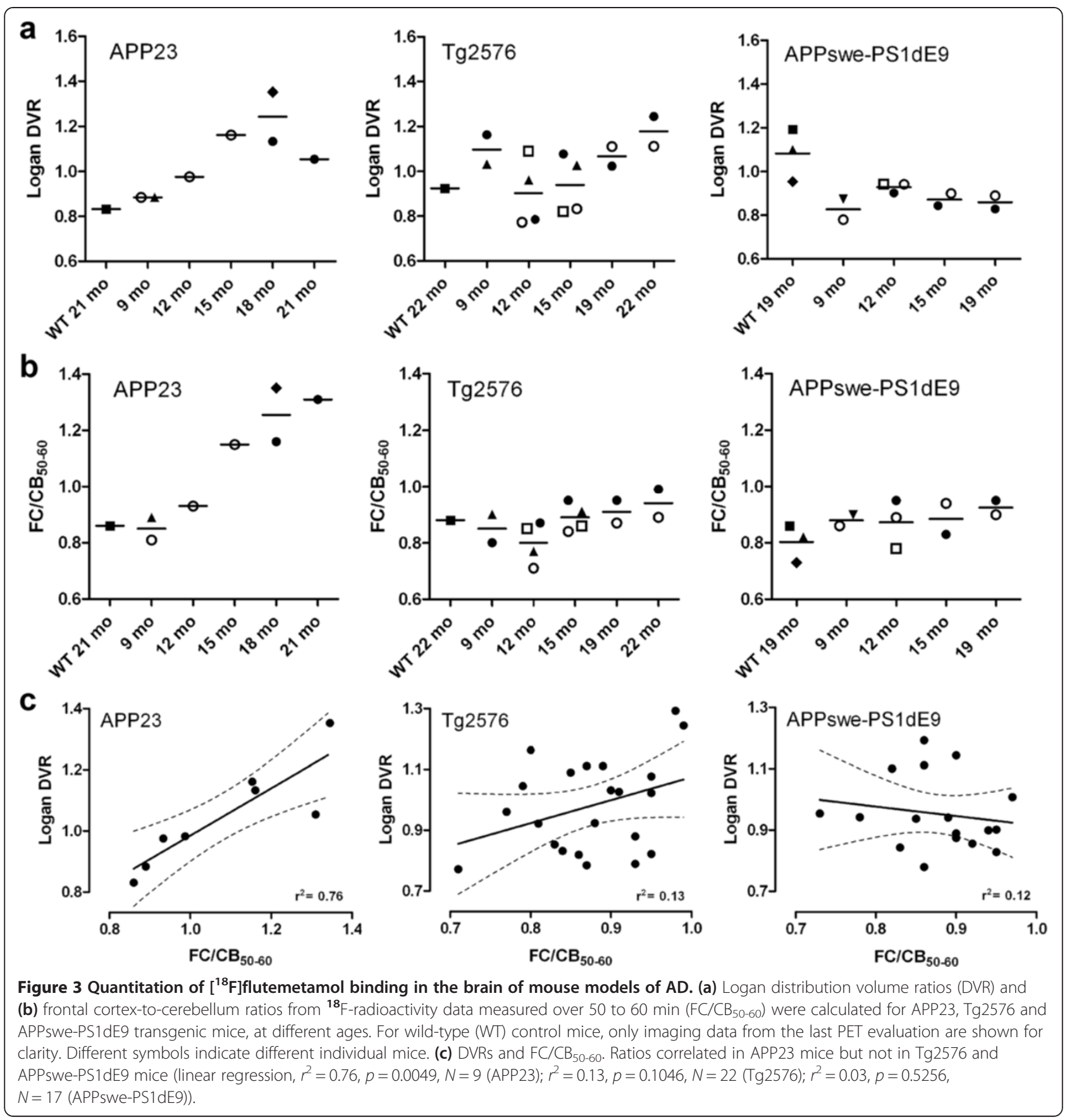

in the cerebral and cerebellar white matter in all evaluated TG and WT mice (Figure 5a).

\section{Ex vivo biodistribution}

${ }^{18}$ F-radioactivity uptake in the brain and intracranial structures of WT $\mathrm{C} 57 \mathrm{Bl} / 6 \mathrm{~N}$ animals are shown in Table 3. The highest ${ }^{\mathbf{1 8}} \mathrm{F}$-radioactivity in the brain was measured in the medulla and hindbrain. ${ }^{18} \mathrm{~F}$-radioactivity in the $\mathrm{CB}$ was higher than that in the FC. The highest
${ }^{18}$ F-radioactivity was measured from the structures inside the nasal cavity.

\section{$A \beta$ deposition in the brain}

The same brain sections investigated with ex vivo and in vitro autoradiography were stained with ThS and adjacent sections with an anti-A $\beta_{1-40}$ antibody (Figures 4 and 6) to determine the presence and localization of $\mathrm{A} \beta$ deposits in the brain and their co-localization with $\left[{ }^{\mathbf{1 8}}\right.$ F]flutemetamol binding. In APP23 brains at 21 and 


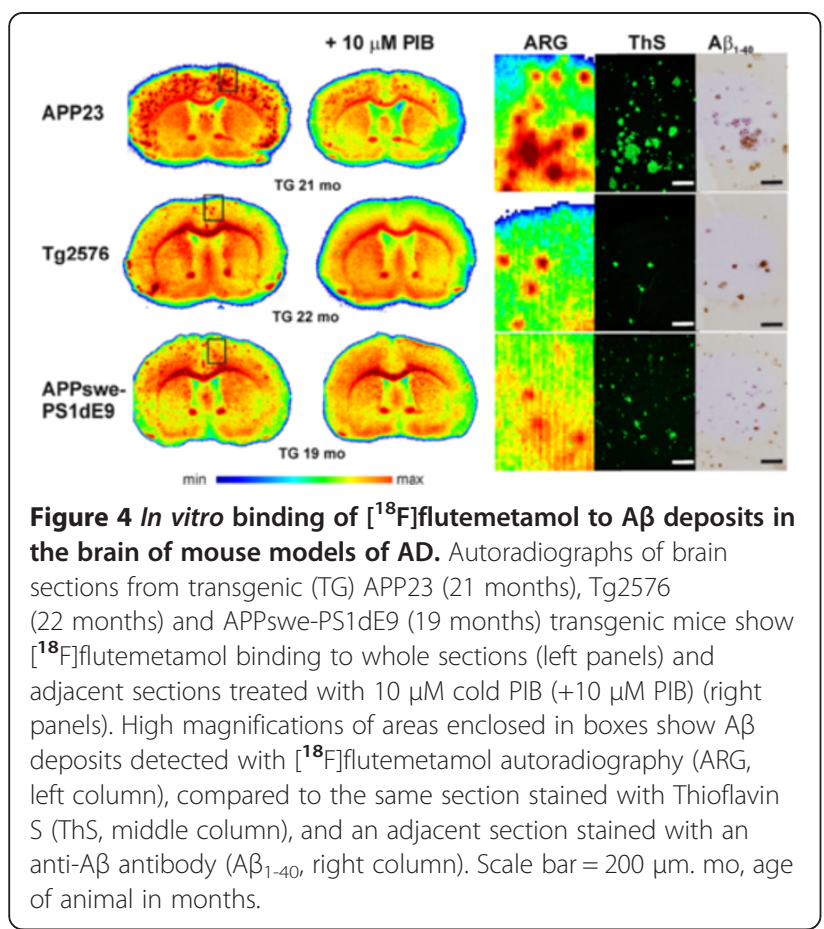

27 months, large, spherical $A \beta$ deposits with a dense core were seen in the FC and in other forebrain regions, but not in the $\mathrm{CB}$. Deposits were prominently stained with ThS and anti-A $\beta_{1-40}$. The plaque load was modest in Tg2576 brain at 22 months, but the deposits were stained with ThS and anti-A $\beta_{1-40}$ antibody and the staining co-localized with $\left[{ }^{\mathbf{1 8}} \mathrm{F}\right]$ flutemetamol binding in the FC. In APPswe-PS1dE9 mice, A $\beta$ deposits were small, spherical and showed low intensity staining with ThS at 19 months. However, deposition was abundant throughout the brain, including the $\mathrm{CB}$, at 19 months. WT mice did not have detectable $A \beta$ deposits (Figure 6).

\section{Discussion}

In the present study, we evaluated the applicability of $\left[{ }^{18} \mathrm{~F}\right]$ flutemetamol to assess brain $\mathrm{A} \beta$ deposition in small animal in vivo PET imaging. $\left[{ }^{\mathbf{1 8}} \mathrm{F}\right]$ Flutemetamol has already been extensively investigated in humans and has received marketing approval as a radiopharmaceutical for the detection of $A \beta$ deposition in subjects with possible AD [12,23-25]. In our previous animal study, we found that the pharmacokinetic properties of $\left[{ }^{\mathbf{1 8}} \mathrm{F}\right]$ flutemetamol in WT rats and mice were suitable for preclinical imaging, and $\left[{ }^{18} \mathrm{~F}\right]$ flutemetamol was found to bind to $\mathrm{A} \beta$ deposits in the $\mathrm{Tg} 2576$ mouse brain, both in vitro and ex vivo [9]. To our knowledge, the present demonstration of principle study is the first to show that it is possible to detect increase in $\left[{ }^{18} \mathrm{~F}\right]$ flutemetamol retention in vivo in the mouse brain parallel with increasing age. However, in the present study, increased $\left[{ }^{18} \mathrm{~F}\right]$

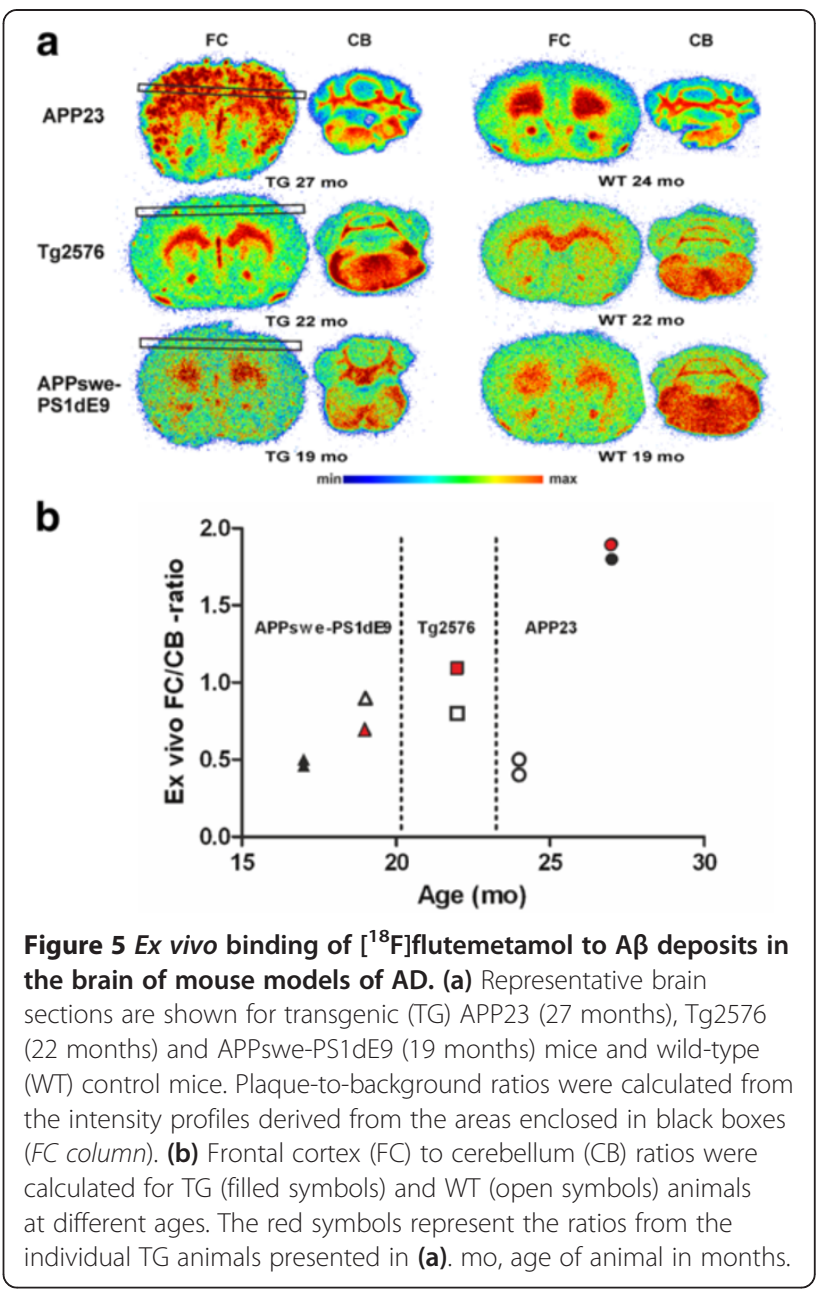

flutemetamol retention was evident only in the transgenic APP23 mice and not in $\operatorname{Tg} 2576$ or APPswePS1dE9 mice. APP23 mouse model is known to have relatively slow plaque deposition and large $\mathrm{A} \beta$ deposits with dense amyloid cores $[4,18]$. $\operatorname{Tg} 2576$ mice have late onset and even slower rate of A $\beta$ deposition than APP23 mice [4]. In APPswe-PS1dE9 mice, small $A \beta$ deposits are present already at earlier age, and deposition is abundant throughout the brain in older animals [4].

Varying results have been found in several small animal imaging studies with $\left[{ }^{11} \mathrm{C}\right] \mathrm{PIB}$, a structural analogue of $\left[{ }^{18} \mathrm{~F}\right]$ flutemetamol which is still considered the golden standard of brain amyloid imaging. A possible explanation for the variation is that different TG mice are likely to express different $A \beta$ isoforms with different amounts of high-affinity binding sites for amyloid tracers [26]. We hypothesized that very high specific activity and lower injected mass of $\left[{ }^{\mathbf{1 8}} \mathrm{F}\right]$ flutemetamol might provide an advantage in some animal models that did not show increased specific binding with $\left[{ }^{11} \mathrm{C}\right] \mathrm{PIB}$ in our previous study, perhaps because of low levels of high-affinity binding sites [4]. In this study, the injected mass of $\left[{ }^{18} \mathrm{~F}\right]$ 


\begin{tabular}{|c|c|c|}
\hline & Mean & SD \\
\hline \multicolumn{3}{|l|}{ Brain areas } \\
\hline Brain & 0.21 & 0.05 \\
\hline Forebrain & 0.19 & 0.05 \\
\hline Midbrain & 0.24 & 0.04 \\
\hline Hindbrain & 0.29 & 0.07 \\
\hline Olfactory bulb & 0.18 & 0.03 \\
\hline Cortex & 0.14 & 0.02 \\
\hline Cerebellum & 0.19 & 0.06 \\
\hline Medulla & 0.86 & 0.20 \\
\hline \multicolumn{3}{|l|}{ Extracranial tissue } \\
\hline Blood & 0.32 & 0.01 \\
\hline Plasma & 0.52 & 0.02 \\
\hline Erythrocytes & 0.12 & 0.01 \\
\hline Cranial bone & 0.83 & 0.13 \\
\hline Submandibular salivary gland & 0.16 & 0.02 \\
\hline Sublingual gland & 0.28 & 0.03 \\
\hline Harderian gland & 0.36 & 0.05 \\
\hline Eyes & 0.93 & 0.11 \\
\hline Nasal cavity & 1.89 & 0.47 \\
\hline
\end{tabular}

Uptake of $\left[{ }^{18} \mathrm{~F}\right]$ flutemetamol in the brain and adjacent tissues of $\mathrm{C} 57 \mathrm{BI} / 6 \mathrm{~N}$ mice at 60 min post-injection of the tracer $(N=4)$. Values are presented as percentage of injected dose per gram of tissue (\% ID/g).

flutemetamol was less than $5.5 \mathrm{ng}$ in all in vivo cases $(N=48)$. This is even at its worst ten times less than previously reported with $\left[{ }^{11} \mathrm{C}\right] \mathrm{PIB}(68 \pm 23 \mathrm{ng} ; N=50$ [4]). However, the results revealed that the use of a tracer with high specific radioactivity did not as such provide any advantage in PET imaging of APPswePS1dE9 mice in vivo. In APPswe-PS1dE9 mice, plaque deposition was abundant throughout the brain (including the $\mathrm{CB}$ ) at 19 months, but plaque composition appeared to be different from the other TG models, with only small fibrillar deposits that could bind ThS and related $A \beta$ imaging agents. In Tg2576 mice, modest increases in DVR and $\mathrm{FC} / \mathrm{CB}_{50-60}$ ratio were seen as the individual transgenic mice aged. In a previous study with $\left[{ }^{11} \mathrm{C}\right] \mathrm{PIB}$ and Tg2576 mice, no such trend was seen [4]. In addition, $\left[{ }^{18} \mathrm{~F}\right]$ flutemetamol did bind to $A \beta$ in the cortical sections from Tg2576 animals, both ex vivo and in vitro, consistent with previous ex vivo results [9]. However, the amount of plaques was modest even at 22-month-old animals, explaining the modest increases in in vivo binding ratios. We concluded that Tg2576 and APPswe-PS1dE9 mouse models are not suited to small animal imaging studies with tracers that shared binding sites with $\left[{ }^{11} \mathrm{C}\right] \mathrm{PIB}$ and $\left[{ }^{\mathbf{1 8}} \mathrm{F}\right]$ flutemetamol, due to their plaque structure or low plaque load.
Our study is difficult to compare with previous small animal amyloid imaging PET studies that used other ${ }^{\mathbf{1 8}} \mathrm{F}$ labelled tracers, due to the differences in tracers, quantitation methods and animal models used. One previous study did not observe increased cortical tracer retention with $\left[{ }^{18}\right.$ F]FDDNP in 13 to 15-month-old Tg2576 mice [27]. The authors concluded that specific $\left[{ }^{18}\right.$ F]FDDNP binding was insufficient and that insufficient spatial resolution and partial volume effects (PVE) limited the precision of measurements in small VOIs [27]. However, in a more recent study with $\left[{ }^{\mathbf{1 8}} \mathrm{F}\right]$ florbetaben, $\mathrm{A} \beta$ deposition was longitudinally followed in the APPswe mouse model from age 13 to 20 months, and the results were consistent with our results with $\left[{ }^{\mathbf{1 8}} \mathrm{F}\right]$ flutemetamol in APP23 mice. In that study, the PET results agreed well with histopathological brain $A \beta$, and differentiation was further improved when a PVE correction was applied $[10,28]$. Using the APP-PS1-21 mouse model, also specific binding of $\left[{ }^{\mathbf{1 8}} \mathrm{F}\right]$ florbetapir was shown to increase from age 3 to 8 months; however, no further increase was detected at 12 months compared to the baseline scan at 3 months [11]. At the end of synthesis, the specific activities of $\left[{ }^{\mathbf{1 8}} \mathrm{F}\right]$ florbetaben (80 GBq/ $\mathrm{mmol},[10])$ and $\left[{ }^{\mathbf{1 8}} \mathrm{F}\right]$ florbetapir $(150$ to $220 \mathrm{GBq} / \mu \mathrm{mol},[11])$ were much lower than the specific activity of $\left[{ }^{18} \mathrm{~F}\right]$ flutemetamol in this study $(>1 \mathrm{TBq} / \mu \mathrm{mol})$. This difference further supports the higher importance of the chosen mouse model over high specific activity of the tracer for successful imaging results.

Similarly to human studies, the CB has usually been used as a reference region in small animal amyloid imaging studies. However, several limitations should be considered when applying this approach. In the mouse brain, the white and grey matter cannot be distinguished when the reference region VOIs are drawn over the $C B$, due to its small size. As a result, because all ${ }^{18} \mathrm{~F}$-labelled $\beta$-amyloid imaging tracers typically exhibit prominent white matter binding, the concentration of radioactivity in the $\mathrm{CB}$ can be higher than that in the cortical grey matter ROIs. In our study, DVRs were less than unity in WT animals and in young TG animals, which presumably had only modest plaque loads. Negative $\mathrm{BP}_{\mathrm{ND}}$ values for WT and young TG mice were also previously reported for $\left[{ }^{18} \mathrm{~F}\right]$ florbetaben. Only TG mice that were 16 and 20 months old showed positive $\mathrm{BP}_{\mathrm{ND}} \mathrm{S}(0.04 \pm$ 0.07 and $0.10 \pm 0.11$, respectively) [10]. For small animal imaging, tracers with low non-specific binding to white matter would be beneficial, such as the novel ${ }^{18} \mathrm{~F}$ labelled fluoropyridyl derivative, BAY 1008472, or the benzofuran ligand $\left[{ }^{18} \mathrm{~F}\right] \mathrm{AZD} 4694$ [29,30]. Moreover, for APPswe-PS1dE9 mice, the CB is not a suitable reference region because $A \beta$ deposits are present at 19 months of age.

Imaging of small structures in the mouse brain, of a size close to the spatial resolution of the PET scanner, 


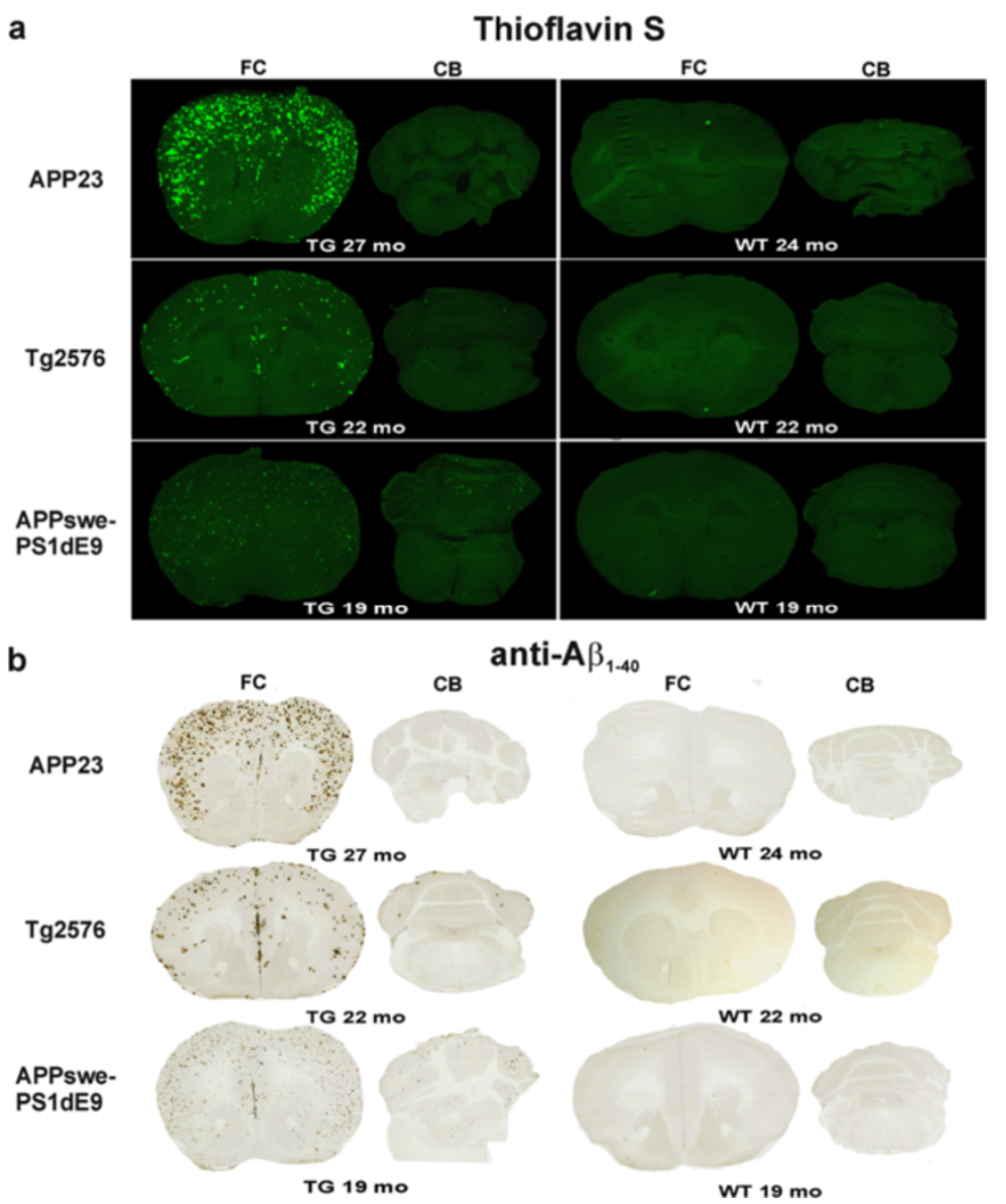

Figure 6 A $\boldsymbol{\beta}$ deposition in the brain of mouse models of AD. (a) Representative images show Thioflavin S staining for transgenic (TG) APP23 (27 months), Tg2576 (22 months) and APPswe-PS1dE9 (19 months) mice and wild-type (WT) control mice in the same sections used for ex vivo evaluation of $\left[^{\mathbf{1 8}}\right.$ F]flutemetamol binding in Figure 5. (b) Adjacent sections from TG APP23 (27 months), Tg2576 (22 months) and APPswe-PS1dE9 (19 months) mice and WT control mice were stained with specific anti-A $\beta_{1-40}$ antibody mo, age of animal in months.

will inevitably be affected by PVEs; thus, measurable signals will be less precise than those achievable with digital autoradiography. Consistent with previous $\left[{ }^{18} \mathrm{~F}\right]$ florbetaben and $\left[{ }^{18} \mathrm{~F}\right]$ florbetapir studies, the $\mathrm{FC} / \mathrm{CB}$ ratios observed in our study with $\left[{ }^{\mathbf{1 8}} \mathrm{F}\right]$ flutemetamol with ex vivo autoradiography (1.8 and 1.9 , respectively, at 30 min p.i.) were higher than that observed with in vivo PET (1.3 at 30 to 35 min p.i.) for old APP23 mice. Adding PVE correction could further improve quantitation of $\left[{ }^{18} \mathrm{~F}\right]$ flutemetamol PET data, especially in animals with still only modest plaque load. Also, spillover from tissues close to the brain could introduce errors to the VOI-based analysis method in mice. We observed high radioactivity in close proximity to the brain in vivo, and subsequent ex vivo tissue counting experiments confirmed that significant radioactivity was located outside of the brain, inside the nasal cavity. In addition, ${ }^{18} \mathrm{~F}$-radioactivity concentrations detected in the mouse cranial bone $(0.83 \pm 0.13 \% \mathrm{ID} / \mathrm{g}$ at $30 \mathrm{~min})$ were higher than those previously reported in rats $(0.04 \pm 0.01 \% \mathrm{ID} / \mathrm{g}$ at $30 \mathrm{~min}[9])$; this suggests that more $\left[{ }^{\mathbf{1 8}} \mathrm{F}\right]$ flutemetamol defluorination could be taking place in mice than in rats, reflecting more active metabolism. However, spillover from these structures would presumably lead to similar overestimation in the brains of all three TG mouse models.

One limitation of the present study was the small number of transgenic animals, especially the ones that could be imaged repeatedly over multiple time points. However, we wanted to evaluate the applicability of $\left[{ }^{18} \mathrm{~F}\right]$ flutemetamol PET to small animal imaging in three different transgenic models even with limited statistical power, rather than in only one transgenic model with higher sample size and better statistical power. This demonstration of principle type of study was still able to show clear increasing trend in $\left[{ }^{18} \mathrm{~F}\right]$ flutemetamol binding in aging APP23 mice and the lack of binding in Tg2576 and APPswe-PS1dE9 mice. Another limitation was that 
we could not perform ex vivo studies for all of the female mice imaged in vivo; however, the brain sections from these mice were used for in vitro binding experiments, and additional ex vivo studies were performed later, with aged males. Male APP23 mice were reported to show slightly slower deposition of $A \beta$ plaques compared to females [17], but these mice were 27 months old; thus, $A \beta$ deposition was abundant. In addition, a hybrid PET/MRI scanner with better spatial resolution and MR details of the brain would better serve the purposes of similar experiments.

\section{Conclusions}

In vivo small animal imaging of brain $\mathrm{A} \beta$ with $\left[{ }^{18} \mathrm{~F}\right]$ flutemetamol, similarly to its structural analogue $\left[{ }^{11} \mathrm{C}\right] \mathrm{PIB}$, is more dependent on which $\mathrm{AD}$ mouse model is used than its high specific activity. In this study, $A \beta$ deposition in the brain could only be followed in vivo in APP23 mice. However, for its practical benefits, such as more efficient use of the produced tracer batches, $\left[{ }^{18} \mathrm{~F}\right]$ flutemetamol imaging with a suitable mouse model like APP23 is an attractive alternative.

\section{Abbreviations}

AD: Alzheimer's disease; $A \beta$ : beta-amyloid; FC: frontal cortex; DVR: distribution volume ratio; $C B$ : cerebellum; $\left[{ }^{11} \mathrm{C}\right] \mathrm{PIB}$ : $\left[{ }^{11} \mathrm{C}\right]$ Pittsburgh compound $\mathrm{B}$; PET: positron emission tomography; TG: transgenic; WT: wild-type; APP: amyloid precursor protein; CT: computed tomography; VOI: volume of interest; ROI: region of interest; ThS: Thioflavin S.

\section{Competing interests}

The authors declare that they have no competing interests.

\section{Authors' contributions}

AS contributed to the design of the study, acquired, analysed and interpreted the PET data and histological and immunohistochemical stainings. AS drafted the manuscript. JR participated in the design of the study and carried out in vitro PET experiments. FL participated in the immunohistochemical stainings and performance of PET experiments. OE performed the radiochemical synthesis of $\left[{ }^{18} \mathrm{~F}\right]$ flutemetamol. MS and GF participated in the design of the animal studies and revised the manuscript critically. MS drafted and revised the manuscript critically for its intellectual content. OS, JR and MHS contributed to the conception, design and coordination of the study, revised the manuscript critically for its intellectual content and gave final approval for the published version. MHS helped to draft the manuscript. All authors read and approved the final manuscript.

\section{Acknowledgements}

We thank the staff of the Accelerator Laboratory, Radiopharmaceutical Chemistry Laboratory, and MediCity research laboratory for assistance; Mr. Vesa Oikonen for modelling expertise and Professor Heikki Tanila for kindly providing the aged APPswe-PS1dE9 mice. The APP23 mice were used with the kind permission of Novartis Pharma, Switzerland. The supply of materials by GE Healthcare for $\left[{ }^{18} \mathrm{~F}\right]$ flutemetamol synthesis is gratefully acknowledged. This study was funded by the European Community's Seventh framework Programmes (FP7/2007-2013) under grant agreements no. 212043 and HEALTH-F2-20011-278850 (INMiND), by clinical grants from the Turku University Hospital (EVO), Academy of Finland, and the Finnish Cultural Foundation.

\section{Author details}

${ }^{1}$ Medicity/PET Preclinical Laboratory, Turku PET Centre, University of Turku, Tykistökatu 6 A, Turku 20520, Finland. ${ }^{2}$ Radiopharmaceutical Chemistry Laboratory, Turku PET Centre, University of Turku, Porthaninkatu 3, Turku 20500, Finland. ${ }^{3}$ Mario Negri Institute for Pharmacological Research, Milan
20156, Italy. ${ }^{4}$ Department of Pharmacology, Drug Development and Therapeutics, University of Turku, Kiinamyllynkatu 10, Turku 20520, Finland. ${ }^{5}$ Unit of Clinical Pharmacology, TYKSLAB, Turku University Hospital, Kiinamyllynkatu 10, Turku 20520, Finland. ${ }^{6}$ Turku PET Centre, University of Turku, Turku 20521, Finland.

Received: 23 May 2014 Accepted: 2 July 2014

Published: 1 August 2014

\section{References}

1. Hardy J, Selkoe DJ: The amyloid hypothesis of Alzheimer's disease: progress and problems on the road to therapeutics. Science 2002, 297:353-356.

2. Salloway S, Sperling R, Fox NC, Blennow K, Klunk W, Raskind M, Sabbagh M, Honig LS, Porsteinsson AP, Ferris S, Reichert M, Ketter N, Nejadnik B, Guenzler V, Miloslavsky M, Wang D, Lu Y, Lull J, Tudor IC, Liu E, Grundman $M$, Yuen E, Black R, Brashear HR: Two phase 3 trials of bapineuzumab in mild-to-moderate Alzheimer's disease. N Engl J Med 2014, 370:322-333.

3. Rinne JO, Brooks DJ, Rossor MN, Fox NC, Bullock R, Klunk WE, Mathis CA, Blennow K, Barakos J, Okello AA, Rodriguez Martinez de Liano S, Liu E, Koller M, Gregg KM, Schenk D, Black R, Grundman M: 11C-PiB PET assessment of change in fibrillar amyloid-beta load in patients with Alzheimer's disease treated with bapineuzumab: a phase 2, double-blind, placebocontrolled, ascending-dose study. Lancet Neurol 2010, 9:363-372.

4. Snellman A, López-Picón FR, Rokka J, Salmona M, Forloni G, Scheinin M, Solin O, Rinne JO, Haaparanta-Solin M: Longitudinal amyloid imaging in mouse brain with 11C-PIB: comparison of APP23, Tg2576, and APPswe-PS1dE9 mouse models of Alzheimer disease. J Nucl Med 2013, 54:1434-1441.

5. Toyama H, Ye D, Ichise M, Liow JS, Cai L, Jacobowitz D, Musachio JL, Hong J, Crescenzo M, Tipre D, Lu JQ, Zoghbi S, Vines DC, Seidel J, Katada K, Green MV, Pike WW, Cohen RM, Innis RB: PET imaging of brain with the beta-amyloid probe, [11C]6-OH-BTA-1, in a transgenic mouse model of Alzheimer's disease. Eur J Nucl Med Mol Imaging 2005, 32:593-600.

6. Klunk WE, Lopresti BJ, Ikonomovic MD, Lefterov IM, Koldamova RP, Abrahamson EE, Debnath ML, Holt DP, Huang GF, Shao L, DeKosky ST, Price JC, Mathis CA: Binding of the positron emission tomography tracer Pittsburgh compound-B reflects the amount of amyloid-beta in Alzheimer's disease brain but not in transgenic mouse brain. J Neurosci 2005, 25:10598-10606.

7. Manook A, Yousefi BH, Willuweit A, Platzer S, Reder S, Voss A, Huisman M, Settles M, Neff F, Velden J, Schoor M, von der Kammer H, Wester HJ, Schwaiger M, Henriksen G, Drzezga A: Small-animal PET imaging of amyloid-beta plaques with [C]PiB and its multi-modal validation in an APP/PS1 mouse model of Alzheimer's disease. PLoS One 2012, 7:e31310.

8. Maeda J, Ji B, Irie T, Tomiyama T, Maruyama M, Okauchi T, Staufenbiel M, Iwata N, Ono M, Saido TC, Suzuki K, Mori H, Higuchi M, Suhara T: Longitudinal, quantitative assessment of amyloid, neuroinflammation, and anti-amyloid treatment in a living mouse model of Alzheimer's disease enabled by positron emission tomography. J Neurosci 2007, 27:10957-10968.

9. Snellman A, Rokka J, Lopez-Picon FR, Eskola O, Wilson I, Farrar G, Scheinin M, Solin O, Rinne JO, Haaparanta-Solin M: Pharmacokinetics of [(18)F] flutemetamol in wild-type rodents and its binding to beta amyloid deposits in a mouse model of Alzheimer's disease. Eur J Nucl Med Mol Imaging 2012, 39:1784-1795.

10. Rominger A, Brendel M, Burgold S, Keppler K, Baumann K, Xiong G, Mille E, Gildehaus FJ, Carlsen J, Schlichtiger J, Niedermoser S, Wängler B, Cumming P, Steiner H, Herms J, Haass C, Bartenstein P: Longitudinal assessment of cerebral $\beta$-amyloid deposition in mice overexpressing Swedish mutant $\beta$-amyloid precursor protein using 18F-florbetaben PET. J Nucl Med 2013, 54:1127-1134.

11. Poisnel G, Dhilly M, Moustié O, Delamare J, Abbas A, Guilloteau D, Barré L: PET imaging with [18F]AV-45 in an APP/PS1-21 murine model of amyloid plaque deposition. Neurobiol Aging 2012, 33:2561-2571.

12. Vandenberghe $R$, Van Laere K, Ivanoiu A, Salmon E, Bastin C, Triau E, Hasselbalch S, Law I, Andersen A, Korner A, Minthon L, Garraux G, Nelissen N, Bormans G, Buckley C, Owenius R, Thurfjell L, Farrar G, Brooks DJ: 18F-flutemetamol amyloid imaging in Alzheimer disease and mild cognitive impairment: a phase 2 trial. Ann Neurol 2010, 68:319-329. 
13. Hatashita S, Yamasaki H, Suzuki Y, Tanaka K, Wakebe D, Hayakawa H: [18F] Flutemetamol amyloid-beta PET imaging compared with [11C]PIB across the spectrum of Alzheimer's disease. Eur J Nucl Med Mol Imaging 2014, 41:290-300.

14. Rinne JO, Wong DF, Wolk DA, Leinonen V, Arnold SE, Buckley C, Smith A, McLain R, Sherwin PF, Farrar G, Kailajärvi M, Grachev ID: [(18)F] Flutemetamol PET imaging and cortical biopsy histopathology for fibrillar amyloid $\beta$ detection in living subjects with normal pressure hydrocephalus: pooled analysis of four studies. Acta Neuropathol 2012, 124:833-845.

15. Wolk DA, Grachev ID, Buckley C, Kazi H, Grady MS, Trojanowski JQ, Hamilton $\mathrm{RH}$, Sherwin $\mathrm{P}, \mathrm{McLain} \mathrm{R}$, Arnold SE: Association between in vivo fluorine 18-labeled flutemetamol amyloid positron emission tomography imaging and in vivo cerebral cortical histopathology. Arch Neurol 2011, 68:1398-1403.

16. Leinonen V, Rinne JO, Virtanen KA, Eskola O, Rummukainen J, Huttunen J, von Und Zu Fraunberg M, Nerg O, Koivisto AM, Rinne J, Jääskeläinen JE, Buckley C, Smith A, Jones PA, Sherwin P, Farrar G, McLain R, Kailajärvi M, Heurling K, Grachev ID: Positron emission tomography with [18F] flutemetamol and [11C]PiB for in vivo detection of cerebral cortical amyloid in normal pressure hydrocephalus patients. Eur J Neurol 2013, 20:1043-1052

17. Sturchler-Pierrat C, Abramowski D, Duke M, Wiederhold KH, Mistl C, Rothacher S, Ledermann B, Bürki K, Frey P, Paganetti PA, Waridel C, Calhoun ME, Jucker M, Probst A, Staufenbiel M, Sommer B: Two amyloid precursor protein transgenic mouse models with Alzheimer disease-like pathology. Proc Natl Acad Sci U S A 1997, 94:13287-13292.

18. Calhoun ME, Wiederhold KH, Abramowski D, Phinney AL, Probst A Sturchler-Pierrat C, Staufenbiel M, Sommer B, Jucker M: Neuron loss in APP transgenic mice. Nature 1998, 395:755-756.

19. Hsiao K, Chapman P, Nilsen S, Eckman C, Harigaya Y, Younkin S, Yang F, Cole G: Correlative memory deficits, Abeta elevation, and amyloid plaques in transgenic mice. Science 1996, 274:99-102.

20. Jankowsky JL, Fadale DJ, Anderson J, Xu GM, Gonzales V, Jenkins NA, Copeland NG, Lee MK, Younkin LH, Wagner SL, Younkin SG, Borchelt DR: Mutant presenilins specifically elevate the levels of the 42 residue beta-amyloid peptide in vivo: evidence for augmentation of a 42-specific gamma secretase. Hum Mol Genet 2004, 13:159-170.

21. Xiong H, Callaghan D, Wodzinska J, Xu J, Premyslova M, Liu QY, Connelly J, Zhang W: Biochemical and behavioral characterization of the double transgenic mouse model (APPswe/PS1dE9) of Alzheimer's disease. Neurosci Bull 2011, 27:221-232.

22. Logan J, Fowler JS, Volkow ND, Wang GJ, Ding YS, Alexoff DL: Distribution volume ratios without blood sampling from graphical analysis of PET data. J Cereb Blood Flow Metab 1996, 16:834-840.

23. Koole M, Lewis DM, Buckley C, Nelissen N, Vandenbulcke M, Brooks DJ, Vandenberghe $\mathrm{R}$, Van Laere $\mathrm{K}$ : Whole-body biodistribution and radiation dosimetry of 18F-GE067: a radioligand for in vivo brain amyloid imaging. J Nucl Med 2009, 50:818-822.

24. Nelissen N, Van Laere K, Thurfjell L, Owenius R, Vandenbulcke M, Koole M, Bormans G, Brooks DJ, Vandenberghe R: Phase 1 study of the Pittsburgh compound $\mathrm{B}$ derivative 18F-flutemetamol in healthy volunteers and patients with probable Alzheimer disease. J Nucl Med 2009, 50:1251-1259.

25. Duara R, Loewenstein DA, Shen Q, Barker W, Potter E, Varon D, Heurlin K, Vandenberghe R, Buckley C: Amyloid positron emission tomography with (18)F-flutemetamol and structural magnetic resonance imaging in the classification of mild cognitive impairment and Alzheimer's disease. Alzheimers Dement 2013, 9:295-301.

26. Levine H, Walker LC: Molecular polymorphism of Abeta in Alzheimer's disease. Neurobiol Aging 2010, 31:542-548.

27. Kuntner C, Kesner AL, Bauer M, Kremslehner R, Wanek T, Mandler M, Karch $R$, Stanek J, Wolf T, Müller M, Langer O: Limitations of small animal PET imaging with [18F]FDDNP and FDG for quantitative studies in a transgenic mouse model of Alzheimer's disease. Mol Imaging Biol 2009, $11: 236-240$

28. Brendel M, Delker A, Rötzer C, Böning G, Carlsen J, Cyran C, Mille E, Gildehaus FJ, Cumming P, Baumann K, Steiner H, Haass C, Herms J, Bartenstein $P$, Rominger $A$ : Impact of partial volume effect correction on cerebral $\beta$-amyloid imaging in APP-Swe mice using [(18)F]-florbetaben PET. Neuroimage 2014, 84:843-853.
29. Juréus $A$, Swahn BM, Sandell J, Jeppsson F, Johnson AE, Johnström P, Neelissen JA, Sunnemark D, Farde L, Svensson SP: Characterization of AZD4694, a novel fluorinated Abeta plaque neuroimaging PET radioligand. J Neurochem 2010, 114:784-794.

30. Brockschnieder D, Schmitt-Willich H, Heinrich T, Varrone A, Gulyás B, Toth M, Andersson J, Boemer U, Krause S, Friebe M, Dinkelborg L, Halldin C, Dyrks T: Preclinical characterization of a novel class of $18 \mathrm{~F}$-labeled PET tracers for amyloid- $\beta$. J Nucl Med 2012, 53:1794-1801.

doi:10.1186/s13550-014-0037-3

Cite this article as: Snellman et al: In vivo PET imaging of beta-amyloid deposition in mouse models of Alzheimer's disease with a high specific activity PET imaging agent $\left[{ }^{18} \mathrm{~F}\right]$ flutemetamol. EJNMMI Research 2014 4:37.

\section{Submit your manuscript to a SpringerOpen ${ }^{\circ}$ journal and benefit from:}

- Convenient online submission

- Rigorous peer review

- Immediate publication on acceptance

- Open access: articles freely available online

- High visibility within the field

- Retaining the copyright to your article

Submit your next manuscript at springeropen.com 